\section{A SERO-ENZYME DIAGNOSIS OF SYPHILIS}

\section{F. W. BAESLACK, M.A., M.D. DETROIT}

The fact that the formation of proteolytic enzymes in the blood may be stimulated through the parenteral introduction of proteins into the organism led to the discovery of such enzymes in certain normal and pathologic conditions in which complex proteins are swept into the circulation. The process of cleavage through these enzymes takes place whenever proteins not normally occurring in the circulation find their way into it, be this either the result of physiologic processes as in pregnancy, or due to the action of certain pathogenic organisms which by their presence bring about abnormal changes in the cell protoplasm. Within certain limits the organism will be stimulated by the presence of these complex proteins in the blood to the production of enzymes capable of splitting them into their simpler components, which are either assimilated or eliminated by the organism. The function of these enzymes in the blood is in this respect similar to the digestive ferments in the gastro-intestinal tract, in that they split the specific substances which.make up our food into simple or native protein molecules capable of assimilation.

The discovery of chorionic epithelium in the blood during pregnancy by Schmorl and Veit induced Abder.halden to study the action of such blood-serum on proteins. As a result of these studies, Abderhalden ${ }^{1}$ developed the method for the diagnosis of pregnancy, using placental tissue for the reaction. Freund and Abderhalden ${ }^{2}$ extended the application of this method to the diagnosis of neoplasms. More recently this method was applied to the diagnosis of tuberculosis by F. Jessen, ${ }^{3}$ while Bundschuh and Roemer, ${ }^{4}$ as well as J. Fischer, made use of it in psychiatry. The scope of this preliminary communication does not permit the citing of the already extensive literature, which demonstrates the applicability of this method to many pathologic conditions.

In view of these facts it seemed advisable to see if the serum of syphilitic patients contained such enzymes as are directed toward the Spirochaeta pallida or the cell degenerations caused by its presence in the body.

The serum normally contains dialyzable substances which will give the reaction when no tissue is added. It is evident from this that not only such reactions must be considered positive which give a dark violet color, but also one must compare the reaction in the two tubes for differences in depth of color.

A positive reaction shows that the serum examined contains substances which have influenced the added protein so that it has become dialyzable, that is, the serum contains proteolytic ferments. The formation of these proteolytic ferments, which are considered specific, presupposes the presence of split protein in the serum. Thus a positive reaction proves (1) the entrance into the blood of substances foreign to it, and (2) the formation of a specific proteolytic ferment in the serum. The reaction disappears in case of clinical cure, or if the entrance of foreign proteins into the blood-stream ceases, and we may assume that the organism has lost

1. Abderhalden : Müunchen. med. Wchnschr., 1913, No: 13, p. 701. 2 Freund and Abderhalden: München. med. Wchnschr., 1913, No. 14 , p. 763 .

3. Jessen, F.: Med. Klinik, 1913, No. 43, p. 1460

4. Bundschub and Roemer: Deutsch. med. Wchnschr., 1913, No. 42 , p. 2029.

5. Fischer, J.: Deutsch. med. Wchnschr., 1913, No. 44, p. 2138. the power to produce the specific ferments in cases in which the disease is still active. If one considers the course of syphilis in its various forms, which again may differ markedly in themselves, we must realize that aside from the virulence of the infecting agent there must be present in the organism conditions which possibly are the cause of these various manifestations of the disease.

'The tissues made use of in these experiments are the glistening pearly white gummas resulting from the inoculation of rabbits with syphilitic tissue or blood of patients affected with syphilis. The resulting lesions, as pointed out in a previous paper, ${ }^{6}$ are not gummas in the strict sense of the term, but mucoid degeneration of the tissue. These lesions contain the Spirochaeta pallida in large numbers, and practically all the original tissue has undergone degeneration. In addition, these lesions are almost free from blood and so exclude a possible factor of error in the test. By carefully trimming away any apparently sound tissue the gumma are cut into small pieces about $4 \mathrm{c.mm}$. in size, boiled for ten minutes, the water is changed and the tissue boiled again for five minutes. This process is repeated until the water in which the tissue has been boiled no longer gives the color reaction with triketohydrindenhydrate. Then it may either be placed in a sterile bottle with the water. in which it was boiled last, to which a small amount of chloroform and toluol have been added, or the tissue may be dried in vacuo over sulphuric acid and ground into a fine powder, which is kept in an amber-colored glass bottle. If the stopper of the bottle is dipped into toluol the ground-up tissue will be under a toluol vapor.

Before the reaction is undertaken it is well to test the dialyzing thimbles. This is done by soaking them in water and then bringing the water just to a boil. After this has been repeated they are set aside to cool, and some chloroform and toluol are added to the water. The dialyzing thimbles are first tested with fresh unhemolyzed rabbit's serum to find out whether they allow protein to pass. Those thimbles which allow the passage of protein should be discarded. After the dialyzing shells bave been cleaned as described above, the second preliminary test is carried out with a 0.5 per cent. aqueous solution of silk peptone. The shells should allow the amino-acids of the peptone to pass. Shells fulfilling these preliminary conditions may be used for the tests for quite a period, when they should be tested again for any possible flaw. The test is carried out as follows: Eight c.c. of sterilized filtered water are placed in the glass tubes and about 6 drops of toluol are added. Each single test requires three glass tubes and as many shells. The serum, which must not be more than eighteen hours old, should be clear and free from any traces of hemolysis. From 0.8 to 1 c.c. of serum are required for the test. To reduce the sources of error the tissue is boiled again for five minutes before the test is made, and the water in which the tissue was boiled is tested with triketohydrindenhydrate for the presence of amino-acids. The dialyzing shells are picked up with a pair of hemostats; a piece of tissue is placed in the bottom of the first shell with clean forceps. To this is added by the use of a small clean funnel half of the clear serum available, and lastly a few drops of toluol. The outside of the shell is carefully rinsed with distilled water and the shell placed into the glass containing the water and toluol. The glass container is closed with a stopper to prevent evaporation. The sec-

6. Baeslack, F. W.: Jour. Infect. Dis., 1913, xil, 60 . 
ond dialyzing shell receives the same amount of serum and toluol but no tissue, and is otherwise treated as the first. The third shell receives tissue plus an equal amount of sterile distilled water and toluol, but no serum. If two or more serums are tested, one control of tissue will do for all. The tubes are placed into the incubator for from twelve to sixteen hours. By carrying out this test late in the afternoon the testing of the dialysate may be done the following morning.

After removing the dialyzing shell, 5 c.c. of the dialysate are placed into a clean test-tube and 0.2 c.c. of a 1 per cent. aqueous solution of triketohydrindenhydrate are added, and the whole is allowed to boil actively for one minute.
The dialysate of the second tube containing only serum will frequently give a color-reaction. This is due to the presence of amino-acids in the serum. The interpretation of the test depends on the difference in the depth of color. The test is positive if the dialysate from Tube 1 gives a darker color-reaction than that of the second tube. 'The dialysate of the third tube should not give any color-reaction whatever. If the color-reaction of the first and second dialysates are of the same intensity or if the dialysate of the second tube gives a darker violet color than that of the first, the diagnosis is negative.

The entire procedure demands careful, clean technic, which, however, is not difficult to master.

WASSERMANN AND SERO-ENZYME REACTIONS

\begin{tabular}{|c|c|c|c|c|c|c|c|c|c|}
\hline Case & Name & Sex* & Age & $\begin{array}{l}\text { Date in } \\
\text { Clinic, } \\
\text { 1913 }\end{array}$ & $\begin{array}{l}\text { Stage of } \\
\text { Disease }\end{array}$ & Treatment & $\begin{array}{l}\text { Wasser- } \\
\text { mann } \\
\mathbf{R} .\end{array}$ & $\begin{array}{l}\text { Sero- } \\
\text { Enzyme } \\
\text { 'Test }\end{array}$ & $\begin{array}{l}\text { Amt. of } \\
\text { Serum } \\
\text { Used for } \\
\text { Each } \\
\text { Tube,c.c. }\end{array}$ \\
\hline 1 & B. $\mathbf{H}$. & $\sigma^{\pi}$ & 23 & $12 / 12$ & Peginning of second- & None & & + & 0.5 \\
\hline $\begin{array}{l}2 \\
3 \\
4 \\
\mathbf{5} \\
\mathbf{6} \\
\mathbf{7} \\
\mathbf{8}\end{array}$ & $\begin{array}{l}\text { M. } \mathbf{R .} \\
\text { T. } \\
\text { T. } \\
\text { T. } \\
\text { T. } \\
\text { W. } \\
\text { M. } \\
\text { M. } \\
\text { W. } \\
\text { T. }\end{array}$ & $\begin{array}{l}q \\
0 \\
0 \\
0 \\
0 \\
0 \\
0^{\prime \prime} \\
0^{\prime \prime}\end{array}$ & $\begin{array}{l}19 \\
29 \\
28 \\
21 \\
28 \\
\mathbf{3 4} \\
\mathbf{3 9}\end{array}$ & $\begin{array}{l}12 / 12 \\
12 / 15 \\
12 / 15 \\
12 / 17 \\
12 / 17 \\
12 / 19 \\
12 / 19\end{array}$ & $\begin{array}{l}\text { Secondary stage } \\
\text { Primary lesion } \\
\text { Secondary stage } \\
\text { Secondary stage } \\
\text { Tertiary } \\
\text { Primary lesion } \\
\text { Past secondary }\end{array}$ & $\begin{array}{ll} & \begin{array}{l}\text { None } \\
\text { None } \\
\text { None } \\
\text { neosalvarsan } \\
\text { ? }\end{array} \\
0.9 \mathrm{gm} & \begin{array}{l}\text { None } \\
\text { neosalvarsan }\end{array} \\
0.9 \mathrm{gm} . & \mathrm{g} \text {. }\end{array}$ & & + & $\begin{array}{l}0.5 \\
0.5 \\
0.5 \\
0.5 \\
0.3 \\
0.5 \\
0.5\end{array}$ \\
\hline $\begin{array}{r}9 \\
10 \\
11 \\
12 \\
13 \\
14\end{array}$ & $\begin{array}{l}\text { E. o. } \\
\text { F. H. } \\
\text { E. o. } \\
\text { S. H. H. } \\
\text { J. o. } \\
\text { F. W. }\end{array}$ & $\begin{array}{l}0^{*} \\
0^{x} \\
\vdots \\
0^{\prime \prime} \\
0^{x} \\
0^{\prime \prime}\end{array}$ & $\begin{array}{l}42 \\
32 \\
37 \\
26 \\
24 \\
24\end{array}$ & $\begin{array}{l}12 / 29 \\
12 / 23 \\
12 / 23 \\
12 /: 24 \\
12 / 20 \\
12 / 29\end{array}$ & $\begin{array}{l}\text { Primary lesions } \\
\text { Secondary eruption } \\
\text { Secondary eruption } \\
\text { Secondary eruption } \\
\text { Primary lesion } \\
\text { Secondary period } \\
\text { (healed)? }\end{array}$ & $\begin{array}{c}\text { None } \\
\text { None } \\
\text { Potassium lodid } \\
\text { ? } \\
2 \text { inf. intrav. of sal- } \\
\text { varsan }+ \text { mercury }\end{array}$ & & $\begin{array}{l}+ \\
+ \\
+\end{array}$ & $\begin{array}{l}0.5 \\
0.5 \\
0.25 \\
0.5 \\
0.5 \\
0.5\end{array}$ \\
\hline $\begin{array}{l}15 \\
16\end{array}$ & $\begin{array}{l}\text { J. } \\
\text { E. } \mathbf{F} .\end{array}$ & $\sigma^{x}$ & $\begin{array}{l}\mathbf{3 7} \\
\mathbf{2 4}\end{array}$ & $\begin{array}{l}12 / 29 \\
12 / 30\end{array}$ & $\begin{array}{l}\text { Secondary lesions } \\
\text { Syphilitie anemia }\end{array}$ & $\begin{array}{l}\text { or potassium iodid } \\
2 \text { intrav. inj. of sal- }\end{array}$ & & + & $\begin{array}{l}0.5 \\
0.5\end{array}$ \\
\hline 17 & J. P. & $\sigma$ & 26 & $12 / 31$ & Tertiary & sium lodid & & + & 0.5 \\
\hline $\begin{array}{l}18 \\
19 \\
20 \\
21 \\
22 \\
23 \\
24\end{array}$ & $\begin{array}{l}\text { E. } \underset{\text { W. }}{\text { W. }} \\
\text { S. } \\
\text { St. } \\
\text { A. } \\
\text { G. } \\
\text { G. } \\
\text { M. } \\
\text { C. } \\
\text { A. }\end{array}$ & $\begin{array}{l}0^{*} \\
0^{\prime \prime} \\
0 \\
0 \\
0 \\
0 \\
0 \\
0 \\
0\end{array}$ & $\begin{array}{c}25 \\
25 \\
32 \\
33 \\
? \\
? \\
36\end{array}$ & $\begin{array}{l}1 / 2 \\
1 / 2 \\
1 / 2 \\
1 / 5 \\
1 / 5 \\
1 / 5 \\
1 / 5 \\
1 / 7\end{array}$ & $\begin{array}{l}\text { Primary lesion } \\
\text { Secondary } \\
\text { Chancroid } \\
\text { Primary lesion } \\
\text { General paresis } \\
\text { General paresis } \\
\text { Spec. Inf. } 2 \text { yrs. ago ; } \\
\text { no clinical symp- } \\
\text { toms }\end{array}$ & $\begin{array}{c}\text { None } \\
? \\
\text { None } \\
? \text { intrav. inj. of neo- } \\
\text { Ealv. }+ \text { niercury }+\end{array}$ & & $\begin{array}{l} \pm \\
\frac{t}{t} \\
+\end{array}$ & $\begin{array}{l}0.5 \\
0.5 \\
0.5 \\
0.1 \\
0.5 \\
0.5 \\
0.3\end{array}$ \\
\hline $\begin{array}{l}25 \\
26 \\
27 \\
28 \\
\mathbf{2 9} \\
\mathbf{3 0} \\
\mathbf{3 1}\end{array}$ & $\begin{array}{l}\text { M. S. } \\
\text { No. } 235 \\
\text { No. } 252 \\
\text { R. R. } \\
\text { B. C. } \\
\text { M. S. } \\
\text { H. D. }\end{array}$ & 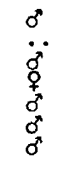 & $\begin{array}{l}34 \\
28 \\
26 \\
39 \\
26 \\
39 \\
45\end{array}$ & $\begin{array}{l}1 / 9 \\
1 / 9 \\
1 / 13 \\
1 / 16 \\
1 / 16 \\
1 / 16 \\
1 / 17\end{array}$ & $\begin{array}{l}\text { Chancroid } \\
\text { Secondary eruption } \\
\text { Late secondaries } \\
\text { Tertiary } \\
\text { Primary lesion } \\
\text { General paresis, } 5 \text { yrs. } \\
\text { Tabes }\end{array}$ & $\begin{array}{c}? \\
? \\
? \\
\text { None } \\
? \\
?\end{array}$ & & $\begin{array}{l}+ \\
+ \\
+ \\
+\end{array}$ & $\begin{array}{l}0.5 \\
0.5 \\
0.3 \\
0.25 \\
0.5 \\
0.5 \\
0.5\end{array}$ \\
\hline 32 & A. C. & $d$ & 50 & $1 / 17$ & Tabes 6 .years & $?$ & & + & $\begin{array}{l}0.0 \\
0.5\end{array}$ \\
\hline $\begin{array}{l}\mathbf{3 3} \\
\mathbf{3 4} \\
\mathbf{3 5}\end{array}$ & $\begin{array}{l}\text { K. M. } \\
\text { A. } \\
\text { A. } \\
\text { C. }\end{array}$ & $\begin{array}{l}d \\
d \\
d\end{array}$ & $\begin{array}{l}\mathbf{5 4} \\
\mathbf{3 8} \\
\mathbf{3 0}\end{array}$ & $\begin{array}{l}1 / 17 \\
1 / 17 \\
1 / 17\end{array}$ & $\begin{array}{l}\text { Tabes } 18 \text { years } \\
\text { General paresis } \\
\text { General paresis }\end{array}$ & ? & & $\frac{t}{\longrightarrow}$ & $\begin{array}{l}0.5 \\
0.5 \\
0.5 \\
0.5\end{array}$ \\
\hline $\begin{array}{l}36 \\
\mathbf{3 7}\end{array}$ & E. $\stackrel{\text { F. }}{\mathbf{L}}$ & $\begin{array}{l}d^{2} \\
\sigma^{2}\end{array}$ & $\begin{array}{l}24 \\
24\end{array}$ & $.1 / 17$ & $\begin{array}{l}\text { General paresis } \\
\text { General paresis }\end{array}$ & $?$ & & $\stackrel{+}{1}$ & $\begin{array}{l}0.5 \\
0.5 \\
0.5\end{array}$ \\
\hline $\begin{array}{l}38 \\
39 \\
40 \\
41\end{array}$ & $\begin{array}{l}\text { W. } \mathbf{M} . \\
\text { C. M. } \\
\text { G. L. } \\
\text { J. Cl. }\end{array}$ & $\begin{array}{l}0 \\
0 \\
\sigma^{\prime \prime} \\
\sigma^{\prime \prime}\end{array}$ & $\begin{array}{l}69 \\
39 \\
40 \\
33\end{array}$ & $\begin{array}{l}1 / 19 \\
1 / 19 \\
1 / 19 \\
1 / 19\end{array}$ & $\begin{array}{l}\text { Tabes } \\
\text { Larly tabes? } \\
\text { Late secondary } \\
\text { Late secondary }\end{array}$ & $\begin{array}{c}\stackrel{?}{?} \\
2 \text { inj. of neosalvarsan } \\
2 \text { inj. of neosalvarsan }\end{array}$ & & + & $\begin{array}{l}0.5 \\
0.5 \\
0.5 \\
0.5 \\
0.5\end{array}$ \\
\hline $\begin{array}{l}42 \\
43 \\
44\end{array}$ & $\begin{array}{l}\text { D. } \mathbf{M} . \\
\text { A. } \mathbf{K} . \\
\text { F. }\end{array}$ & $\begin{array}{l}\delta^{*} \\
0^{2}\end{array}$ & $\begin{array}{l}29 \\
44 \\
36\end{array}$ & $\begin{array}{l}1 / 21 \\
1 / 21 \\
1 / 21\end{array}$ & $\begin{array}{l}\text { Tertiary lesion } \\
\text { Tertiary lesion } \\
\text { Early tertiary }\end{array}$ & Mercury and one inj. & $\frac{++}{++}$ & + & $\begin{array}{l}0.5 \\
0.5 \\
0.5\end{array}$ \\
\hline 45 & Ed. F. & $\sigma^{*}$ & 25 & $1 / 23$ & Primary lesion & None & + & + & 0.5 \\
\hline $\begin{array}{l}46 \\
47 \\
48 \\
49 \\
50\end{array}$ & $\begin{array}{l}\text { o. } \mathbf{W} . \\
\text { M. } \\
\text { A. } \\
\text { A. } \\
\text { A. } \\
\text { A. } \\
\text { K. }\end{array}$ & $\begin{array}{l}0 \\
9 \\
\vdots \\
\vdots \\
0 \\
q\end{array}$ & $\begin{array}{l}18 \\
\mathbf{3 3} \\
\mathbf{2 6} \\
\mathbf{1 3} \\
\mathbf{2 2}\end{array}$ & $\begin{array}{l}1 / 23 \\
1 / 27 \\
1 / 27 \\
1 / 29 \\
1 / 29\end{array}$ & $\begin{array}{l}\text { Chancroid } \\
\text { Tertiary lesion } \\
\text { Secondary stage } \\
\text { Scarlet fever } \\
\text { Scarlet fever }\end{array}$ & $\begin{array}{l}\cdots \cdots \\
\cdots \cdots \\
\cdots \cdots \\
\cdots \cdots\end{array}$ & $\begin{array}{c}+\overline{+}+ \\
\frac{+}{+}\end{array}$ & $\begin{array}{l} \pm \\
\pm\end{array}$ & $\begin{array}{l}0.5 \\
0.5 \\
0.5 \\
0.5 \\
0.5\end{array}$ \\
\hline $\begin{array}{l}\mathbf{5 1} \\
\mathbf{5 2} \\
\mathbf{5 3}\end{array}$ & $\begin{array}{ll}\mathbf{J} . & \mathbf{M} . \\
\mathbf{B} . & \mathbf{H} .\end{array}$ & $\begin{array}{l}0 \\
\vdots \\
\$ \\
0\end{array}$ & $\begin{array}{l}18 \\
\mathbf{2 0} \\
\mathbf{3 9}\end{array}$ & $\begin{array}{c}1813 \\
12 / 18 \\
12 / 18 \\
12 / 18 \\
1914\end{array}$ & $\begin{array}{l}\text { Normal } \\
\text { Normal } \\
\text { Normal }\end{array}$ & 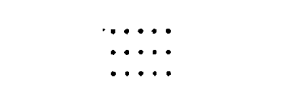 & 二 & $\mp$ & $\begin{array}{l}0.5 \\
0.5 \\
0.5\end{array}$ \\
\hline $\begin{array}{l}54 \\
55\end{array}$ & M. $\mathbf{\text { E. }}$ & $\stackrel{8}{q}$ & $\begin{array}{l}26 \\
26\end{array}$ & $\begin{array}{l}1 / 30 \\
1 / 30\end{array}$ & $\begin{array}{l}\text { Normal } \\
\text { Congenital }\end{array}$ & $\cdots$ & - & $\overline{+}$ & $\begin{array}{l}0.5 \\
0.5\end{array}$ \\
\hline
\end{tabular}

* In this column $\delta$ denotes male and $q$ female. for the result. \& Spinal fluid. 
In addition to the three cases of chancroid (Cases 20, 25 and 46 ), the serums of four normal persons and two scarlet fever patients were tested. The three cases of chancroid gave a negative sero-enzyme reaction and were also negative with the Wassermann reaction, which was true likewise of the serums of the normal persons. The serum of scarlet fever Case 49 was positive with the ox-heart antigen and negative with the fetal liver and rabbit-gumma antigen, while the serum of scarlet fever Case 50 gave a positive Wassermann ( + sign) reaction with the three above-named antigens. Both serums were negative with the sero-enzyme test.

The accompanying table was arranged from the histories taken at the time the patients visited the clinic.

The entire number of fifty-five serums includes fortysix cases of syphilis. Eight serums came from patients in the primary stage of the disease, eighteen from those in the secondary stage, seven from tertiary syphilis, five from tabetics, seven from general paretics and one from a case of congenital lues. The remaining nine serums include four from normal persons, three from cases of chancroid, and two from scarlet fever patients.

Of the two scarlet fever patients, one, Case 50, gave a positive Wassermann with the three antigens employed; while the sero-enzyme reaction was negative. Aside from this case, the results of the Wassermann reaction correspond with the findings of the sero-enzyme reaction in the eight remaining serums. The cerebrospinal fluid obtained from nine cases of tabes and general paresis gave a positive Wassermann reaction, while the seroenzyme test was uniformly negative, demonstrating the absence of the enzyme in the cerebrospinal fluid. This divergence also shows that the factors entering into the Wassermann reaction are distinct from those bringing about the sero-enzyme test. The lack of these enzymes in the cerebrospinal fluid may be due to the relativelv small number of white blood-cells present in this fluid, since the production of these enzymes may depend on these cells, for the serums from patients in this stage of the disease gave a uniformly positive sero-enzyme reaction. Case 14, in which the patient presented himself at the clinic with a recently acquired gonorrhea and gave a history of specific infection followed by prompt treatment, was free from any clinical signs of syphilis. Since both the Wassermann and sero-enzyme tests were negative, it is probable that this patient has been cured.

While the Wassermann reaction at times is negative in the primary stage of syphilis, and was negative in three cases out of eight (Cases 3,9 and 21) in this series, the sero-enzyme reaction was positive in all. Out of the eighteen cases of secondary syphilis, four, Cases 4 , $12,16,26$, gave a negative Wassermann reaction, but alb gave positive sero-enzyme reactions. The specific enzyme present in the serums of syphilitics is probably directed against the degenerated cell proteins rather than against the infecting agent. The sero-enzyme reaction appears to be specific and demonstrable at an earlier period than the complement-fixation test. This may be due to the production of specific enzymes stimulated by minute quantities of protein foreign to the blood, and because these proteins are constantly finding their way into the circulation in the course of this disease. The Wassermann reactions have been carried out with three antigens, and have been repeated in most instances for the purpose of double-checking the results.

I wish to tlfank Dr. R. H. Varny for carrying out some of the Wassermann reactions, and Dr. William E. Keane, and Dr. G. L. Kiefer for giving me access to their clinics.

\section{THE REMOVAL OF THE APPENDIX IN AIL CASES OF APPENDICITIS WITH . LOCALIZED ABSCESS}

VAN BUREN KNOTT, M.D. SlOUX CITY, IOWA

As many inquiries have been received since the publication of a former article ${ }^{1}$ dealing with the removal of the appendix in all cases of appendicitis with localized abscess, I desire again to present the subject for consideration and criticism.

In discussing the subject with many surgeons of large experience I find that the majority still seem inclined to follow the plan which was apparently in universal use many years ago, that is, simple incision and drainage of the abscess, making no effort to remove the appendix unless it presents itself within the confines of the abscess, practically free from adhesions and in fact inviting removal. Furthermore, the trend of the majority of articles dealing with this question, as well as the method of handling these cases at the various large surgical clinics, would indicate that by far the greater number of operators remove the appendix only in a comparatively small percentage of such cases.

The reason usually given by operators who follow this course is that it is unsafe to separate the adhesions forming the boundary of the abscess, thereby during the search for the appendix, liberating pus and septic material into the uncontaminated areas of the peritoneum. This was the opinion held by myself up to some six or seven years ago, my former custom being to remove the appendix only in instances in which such removal was easy and could be accomplished with the separation of few adhesions.

During the past seven years I have operated on 501 cases of appendicular abscess sharply localized. This series does not include any case in which at operation, the general peritoneal cavity was found to be infected, or cases of gangrene of the appendix without the formation of a distinct peri-appendicular abscess. In this series of cases the appendix was removed in every instance at the primary operation whether easily detected within the abscess cavity or whether deeply buried by adhesions.

In the 501 cases six deaths occurred. One patient, a little girl aged 4, died thirty-six hours arter operation, from what cause I do not know, as this operation was done in the country and I could get no clear postoperative history. A man, aged 49 , died sixteen days after operation from cardiac thrombosis. A boy, aged 17, died four days following operation from septicemia. Another patient, a woman, aged 31 , died from septicemia six days after operation. A man aged 27 , died twelve days following operation from postoperative obstruction, further intervention being refused. 'The sixth patient, a man aged 24, died from secondary hemorrhage the third day after operation. The ages of the patients included in this series ranged from 10 months to 84 years.

'The results secured are infinitely better than those I obtained under the old plan of treatment, in which in a large proportion of cases, the appendix was allowed to remain undisturbed, with a resultant mortality of 8 per cent., whereas, in the series of 500 cases of appendicitis with abscess, mentioned above, the appen-

1. Knott, Van Buren: Treatment of Localized Appendicular Abscess, The Journal A. M. A., Aug. 12, 1911, p. 525. 